\title{
EFFECT OF POTASSIUM SOURCES AND RATES ON ARABICA COFFEE YIELD, NUTRITION, AND MACRONUTRIENT EXPORT ${ }^{(1)}$
}

\author{
Mauricio Antonio Cuzato Mancuso ${ }^{(2)}$, Rogério Peres Soratto ${ }^{(3)}$, Carlos Alexandre Costa \\ Crusciol $^{(4)}$ \& Gustavo Spadotti Amaral Castro ${ }^{(5)}$
}

\begin{abstract}
SUMMARY
The use of potassium (K) rock powder can be an alternative for $\mathrm{K}$ supply of crops. Thus, to reduce $\mathrm{K}$ fertilizer imports from abroad, possibilities of extracting this nutrient from Brazilian rocks are being studied. The objective was to evaluate the effect of phonolite rock powder (F2) as K source (Ekosil $\left.{ }^{\circledR}\right)$ on the air-dried fruit yield, nutrition and macronutrient export of Arabica coffee. The experiment was carried out on a dystroferric Red Latosol (Typic Haplorthox), in Piraju, São Paulo State, Brazil, in the 2008/09 and 2009/10 growing seasons. The experimental design was a randomized complete block, in a factorial $2 \times 3+1$ arrangement, with four replications. The treatments consisted of two $\mathrm{K}$ sources $\left(\mathrm{KCl}-58 \%\right.$ of $\mathrm{K}_{2} \mathrm{O}$ and $\mathrm{F} 2$ - $8.42 \% \mathrm{~K}_{2} \mathrm{O}$ ) and three rates $1 / 2-, 1$, and 2 -fold the $\mathrm{K}_{2} \mathrm{O}$ rate recommended for coffee, i.e., 75, 150, and $300 \mathrm{~kg} \mathrm{ha}^{-1}$ of $\mathrm{K}_{2} \mathrm{O}$ ), plus a control (without $\mathrm{K}$ application). Potassium supply increased coffee yield, regardless of the source. Application of source $\mathrm{F} 2$ increased coffee yield similarly to $\mathrm{KCl}$ at the recommended $\mathrm{K}$ rate for coffee (150 kg ha-1 $\left.\mathrm{K}_{2} \mathrm{O}\right)$, proving efficient as $\mathrm{K}$ supply for coffee. Potassium application increased macronutrient export in coffee, especially in the growing season with higher yield.
\end{abstract}

Index terms: Coffea arabica, potassium fertilization, rock powder, agronomic efficiency.

\footnotetext{
(1) Part of Master's Dissertation presented by the first author to the College of Agricultural Sciences, São Paulo State University - FCA/UNESP. Received for publication on May 7, 2013 and approved on July 15, 2014.

(2) $\mathrm{PhD}$ student in Agronomy (Agriculture), FCA/UNESP. Campus of Botucatu. P.O. Box 237. CEP 18603-970 Botucatu (SP), Brazil. E-mail: macmancuso@hotmail.com

(3) Associate Professor, Department of Crop Science, FCA/UNESP. Research award from CNPq. E-mail: soratto@fca.unesp.br

(4) Full Professor, Department of Crop Science, FCA/UNESP. Research award from CNPq. E-mail: crusciol@fca.unesp.br

(5) Analyst, Embrapa Amapá. P.O. Box 10. CEP 68903-419 Macapá (AP), Brazil. E-mail: gustavo.castro@embrapa.br
} 


\title{
RESUMO: PRODUTIVIDADE, NUTRIÇÃO E EXPORTAÇÃO DE MACRONUTRIENTES PELA CULTURA DO CAFÉ ARÁBICA EM RAZÃO DE FONTES E DOSES DE POTÁSSIO
}

\begin{abstract}
A utilização de rochas potássicas moídas ou pó de rocha pode ser uma alternativa para o fornecimento de potássio $(K)$ às culturas. Assim, visando reduzir a importação de fertilizantes potássicos, buscam-se opções para obtenção desse nutriente em rochas brasileiras. Objetivouse com este trabalho avaliar o efeito, como fonte de $K$, de uma rocha fonolito moída (F2), comercialmente denominada Ekosil ${ }^{\circledR}$, na produtividade de grãos "em coco", nutrição $e$ exportação de macronutrientes pela cultura do café arábica. Desenvolveu-se o experimento em um Latossolo Vermelho distroférrico, no município de Piraju, SP, nos anos agrícolas de 2008/ 09 e 2009/10. O delineamento experimental utilizado foi em blocos ao acaso, em esquema fatorial $2 \times 3+1$, com quatro repetições. Os tratamentos foram compostos por duas fontes de $\mathrm{K}\left(\mathrm{KCl}-58 \%\right.$ de $\mathrm{K}_{2} \mathrm{O}$ e $\mathrm{F} 2-8,42 \%$ de $\left.\mathrm{K}_{2} \mathrm{O}\right)$, três doses (1/2, 1 e 2 vezes a dose de $\mathrm{K}_{2} \mathrm{O}$ recomendada para a cultura do café, ou seja, 75, 150 e $300 \mathrm{~kg} \mathrm{ha}^{-1}$ de $\mathrm{K}_{2} \mathrm{O}$ ) e uma testemunha (sem aplicação de K). A aplicação de Kaumentou a produtividade da cultura do café, independentemente da fonte utilizada. O uso da fonte F2 elevou a produtividade de café em coco, com incrementos semelhantes aos proporcionados pelo $\mathrm{KCl}$ na dose de K recomendada para a cultura (150 $\mathrm{kg} \mathrm{ha}^{-1}$ de $\mathrm{K}_{2} \mathrm{O}$ ). A aplicação de Kaumentou a exportação de macronutrientes pela cultura do café, especialmente em ano de maior produtividade.
\end{abstract}

Termos de indexação: Coffea arabica, adubação potássica, pó de rocha, eficiência agronômica.

\section{INTRODUCTION}

Coffee is one of the most widely grown crops in Brazil. The Brazilian coffee production was around 50.8 million bags of $60 \mathrm{~kg}$ of hulled green beans, i.e. an average yield of approximately 24.8 bags ha $^{-1}$ (CONAB, 2013), making the country the world's leading coffee producer. Thus, coffee is still one of the major agricultural export goods, generating wealth and income for the country, apart from its major social functions.

For higher yields, coffee requires great quantities of some macronutrients, including K. Coffee trees need this nutrient as much as $\mathrm{N}$, to build up resistance against especially fungal diseases, aside from preventing water stress by regulating turgor pressure, by influencing stomatal opening and closing. Moreover, K influences coffee cherry and bean formation, by stimulating enzyme activities, as well as carbohydrate synthesis and translocation, thus improving the beverage quality (Malavolta et al., 1997).

An increase in the percentage of empty fruits and a decrease in bean size can be cited as K deficiency symptoms, negatively affecting beverage quality (Matiello et al., 2010). Potassium plays a role in photoassimilated compounds translocation for bean formation, increasing their weight and volume as well as activating maturation (Malavolta et al., 1974), therefore, it is removed in large quantities by coffee, especially from well-nourished trees and in growing seasons with higher yields (Silva et al., 2001).

Brazil is the fourth largest consumer and one of the largest fertilizer importers. Nationwide, $95 \%$ of $\mathrm{K}$ is consumed in fertilizer production, and the most commonly used source of this nutrient is potassium chloride (KCl) (Brasil, 2012). However, it is estimated that around $90 \%$ of the Brazilian demand for $\mathrm{K}$ is covered by importations, since the national industry cannot feed the domestic market (Melamed et al., 2009; Brasil, 2012). Potassium chloride contains the chloride anion $\left(\mathrm{Cl}^{-}\right)$which, among other factors, can damage coffee plants by the high salinity, causing toxicity in plants, aside from reducing polyphenol oxidase activity and thus decreasing the beverage quality (Silva et al., 1999; 2002). It must also be considered that the $\mathrm{Cl}^{-}$raises the cherry moisture and may therefore increase microbial proliferation, causing undesirable fermentation (Malavolta, 1986; Silva et al., 1999).

Because $\mathrm{KCl}$ is a very water-soluble salt, its application may increase the absorption of other cations such as $\mathrm{Ca}$ and $\mathrm{Mg}$ for a short period of time due to the major $\mathrm{Cl}^{-}$concentration. However, after leaching of this anion, the high $\mathrm{K}$ concentration in the soil may reduce the absorption of other cations by plants (Jakobsen, 1993; Clement et al., 2013). Furthermore, the application of very soluble K salts increases leaching losses (Duarte et al., 2013).

For being imported, $\mathrm{KCl}$ becomes expensive in spite of being cheaper than other industrialized $\mathrm{K}$ fertilizers. Reducing Brazil's dependence on imported fertilizers through the exploitation of domestic $\mathrm{K}$ fertilizer sources could remarkably diminish the production costs, causing a significant price drop of agricultural products for consumers. Consequently, it may even increase international market competitiveness (Resende et al., 2006; Cortes et al., 2010)

A viable alternative to supply $\mathrm{K}$ as fertilizer is the rock powder, consisting of finely ground rocks, used 
as nutrient source for plants (Resende et al., 2006; Cortes et al., 2010). The application of rock powder or stonemeal for crops is a long-standing farming practice that saves production costs for being a simple and alternative product with low processing cost. Moreover, it is also applied as supplement with industrialized fertilizers. Furthermore, because of the lower solubility of rock powder, nutrient release is gradual, which decreases leaching losses and soil salinity, apart from the long-term action (Melamed et al., 2009), providing a balanced plant nutrition (Cortes et al., 2010).

Some potassic rock sources contain silicon ( $\mathrm{Si}$ ), a beneficial element to plants, especially when applied with $\mathrm{K}$. Both elements can positively influence the beverage quality, as they reduce the disease incidence and improve coffee foliage and grain uniformity (Chalfoun \& Carvalho, 2002).

This study evaluated the effect of a phonolite rock powder as K source on air-dried fruit yield, nutrition and macronutrient export by Arabica coffee (Coffea arabica L.).

\section{MATERIAL AND METHODS}

The experiment was carried out in Piraju, São Paulo State, Brazil ( $23^{\circ} 11^{\prime} \mathrm{S}, 49^{\circ} 23^{\prime} \mathrm{W} ; 640 \mathrm{~m}$ asl) in a dystroferric Red Latosol (Typic Haplorthox) (Embrapa, 2006), where coffee plants were previously established. According to Köppen's classification, Cwa is the regionally predominant, tropical altitude climate, with dry winters and hot wet summers. During the experiment, monthly rainfall and average temperature were recorded (Figure 1).

The experiment with Arabica coffee (Coffea arabica L.), cultivar Mundo Novo, was planted in February 2006 , in $3.50 \times 0.70 \mathrm{~m}$ spacing $\left(4,082\right.$ plants ha $\left.{ }^{-1}\right)$. The experiment was carried out in the 2008/09 and 2009/10 growing seasons. In August 2008, soil samples were taken from the layers $0-0.20$ and $0.20-0.40 \mathrm{~m}$. At each depth, 10 subsamples were taken below the coffee tree canopies to form a composite sample. This sample was dried and sieved $(<2 \mathrm{~mm})$. Then, chemical and physical properties were determined (Embrapa, 1997; Raij et al., 2001). In the 0-0.20 m layer, the soil characteristics were as follows: $\mathrm{pH}\left(\mathrm{CaCl}_{2}\right), 5.1$; organic matter, $16 \mathrm{~g} \mathrm{dm}^{-3} ; \mathrm{P}_{\text {resin }}, 23 \mathrm{mg} \mathrm{dm}^{-3} ; \mathrm{K}$, $1.1 \mathrm{mmol}_{\mathrm{c}} \mathrm{dm}^{-3} ; \mathrm{Ca}, 39 \mathrm{mmol}_{\mathrm{c}} \mathrm{dm}^{-3} ; \mathrm{Mg}, 15 \mathrm{mmol}_{\mathrm{c}} \mathrm{dm}^{-3}$; $\mathrm{H}+\mathrm{Al}, 31 \mathrm{mmol}_{\mathrm{c}} \mathrm{dm}^{-3}$; CEC, $87 \mathrm{mmol}_{\mathrm{c}} \mathrm{dm}^{-3}$; base saturation, $64 \%$; clay, silt, and sand contents of 488 , 217 , and $295 \mathrm{~g} \mathrm{~kg}^{-1}$, respectively. In the $0.20-0.40 \mathrm{~m}$ layer, the analysis results were as follows: $\mathrm{pH}\left(\mathrm{CaCl}_{2}\right)$, 4.7; organic matter, $13 \mathrm{~g} \mathrm{dm}^{-3} ; \mathrm{P}_{\text {resin }}, 9 \mathrm{mg} \mathrm{dm}^{-3} ; \mathrm{K}$, $1.0 \mathrm{mmol}_{\mathrm{c}} \mathrm{dm}^{-3} ; \mathrm{Ca}, 30 \mathrm{mmol}_{\mathrm{c}} \mathrm{dm}^{-3} ; \mathrm{Mg}, 11 \mathrm{mmol}_{\mathrm{c}} \mathrm{dm}^{-3}$; $\mathrm{H}+\mathrm{Al}, 39 \mathrm{mmol}_{\mathrm{c}} \mathrm{dm}^{-3}$; CEC, $81 \mathrm{mmol}_{\mathrm{c}} \mathrm{dm}^{-3}$; base saturation, $52 \%$; clay, silt, and sand contents of 500 , 224 , and $276 \mathrm{~g} \mathrm{~kg}^{-1}$, respectively.
The experimental design was randomized complete blocks, in $2 \times 3+1$ factorial scheme with four replications. Treatments consisted of two $\mathrm{K}$ sources $\left(\mathrm{KCl}-58 \% \mathrm{~K}_{2} \mathrm{O}\right.$ and $\left.\mathrm{F} 2-8.42 \% \mathrm{~K}_{2} \mathrm{O}\right)$ and three rates (1/2-, 1-, and 2- fold the recommended $\mathrm{K}_{2} \mathrm{O}$ rate for coffee, in other words, 75,150 , and $300 \mathrm{~kg} \mathrm{ha}^{-1} \mathrm{~K}_{2} \mathrm{O}$ ), aside from a control (without $\mathrm{K}$ application). Rates were calculated according to Raij et al. (1997) and applied to an established and already productive coffee field. Each plot consisted of three $6.3 \mathrm{~m}$ long coffee tree rows. Plots were separated from one another by one tree in the row as well as by one tree row. The central row was considered for evaluation, disregarding one tree at each end.

The alternative $\mathrm{K}$ source studied in this work was phonolite rock powder (F2), brand Ekosil ${ }^{\circledR}$. This product from Mineração Curimbaba, a mining company in the region of Poços de Caldas, Minas Gerais, Brazil, had the following chemical properties: $8.42 \% \mathrm{~K}_{2} \mathrm{O}\left(1.2 \% \mathrm{~K}_{2} \mathrm{O}\right.$ soluble in citric acid), $52.5 \%$ $\mathrm{SiO}_{2}\left(12.9 \% \mathrm{SiO}_{2}\right.$ soluble in citric acid), $0.05 \% \mathrm{P}_{2} \mathrm{O}_{5}$, $1.6 \% \mathrm{CaO}, 0.2 \% \mathrm{MgO}, 20.7 \% \mathrm{Al}_{2} \mathrm{O}_{3}$ and $7.5 \% \mathrm{Na}_{2} \mathrm{O}$. The product is nothing more than finely ground phonolite rock, produced to supply nutrients, especially $\mathrm{K}$, to plants. This is a fine-textured rock consisting basically of $\mathrm{K}$ feldspars, whose mineral composition is, predominantly, microcline $\left(\mathrm{KAlSi}_{3} \mathrm{O}_{8}\right)$, orthoclase $\left(\mathrm{KAlSi}_{3} \mathrm{O}_{8}\right)$, andesite $\left[(\mathrm{Na}, \mathrm{Ca})(\mathrm{Si}, \mathrm{Al})_{4} \mathrm{O}_{8}\right]$ and nepheline [(Na,K) $\left.\mathrm{AlSiO}_{4}\right]$ (Cortes et al, 2010; Teixeira et al, 2011). Of potassium chloride $\left(\mathrm{K}_{2} \mathrm{O}\right)$, $58 \%$ was soluble in water.

The treatments were applied by hand in October 2008 and reapplied in November 2009. Both products

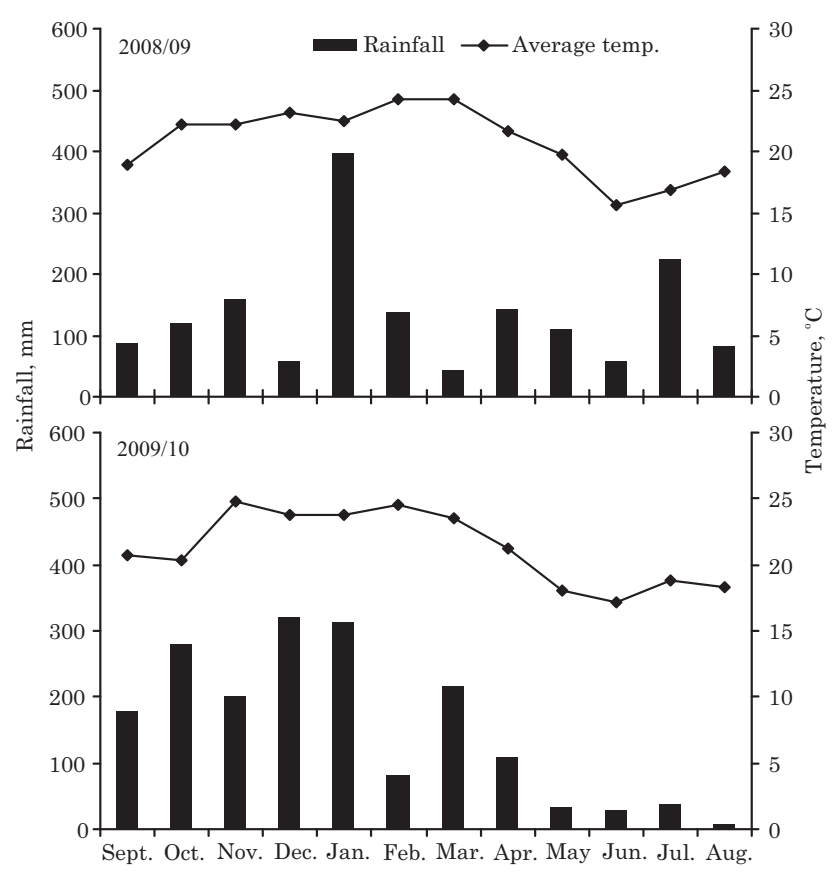

Figure 1. Monthly rainfall and average temperature in the experimental area, from September 2008 to August 2010. 
were uniformly distributed under the coffee canopy. Topdressing of $230 \mathrm{~kg} \mathrm{ha}^{-1}$ of $\mathrm{N}$ (ammonium nitrate) was also applied in both years to the entire experimental area, split in November, January, and March. In February of each year, $0.34 \mathrm{~kg} \mathrm{ha}^{-1}$ of B (boric acid) was applied to the leaves. Weed, pest and disease management was performed according to the producer's criteria.

The leaf concentration of macronutrients $(\mathrm{N}, \mathrm{P}$, $\mathrm{K}, \mathrm{Ca}, \mathrm{Mg}$, and $\mathrm{S}$ ), as well as $\mathrm{Si}$ concentrations were determined in the $3^{\text {rd }}$ pair of leaves from the apex of fruit branches at the mid-height of trees. They were collected in the beginning of the summer (December/ January) of each growing season, according to Raij el al. (1997). Leaf samples were washed with distilled water and oven-dried at $65{ }^{\circ} \mathrm{C}$ for $72 \mathrm{~h}$. Later, the leaves were ground in a Willey mill and chemically evaluated for macronutrients, as described by Malavolta et al. (1997). The same method was applied to determine macronutrients in air-dried coffee fruits, harvested in July of both growing seasons. Leaf Si concentration was evaluated according to Korndörfer et al. (2004).

Five randomly chosen trees within the assessed area of each plot were harvested for coffee yield evaluation. Thus, all coffee fruits were hand-harvested in July 2009 and 2010, and then dried in the sun. It must be mentioned that coffee was harvested when most fruits were in fresh ripe cherry stage (glossy, firm, bright red cherries). After drying, the air-dried fruits were weighed and moisture was adjusted to $12 \%$ moisture content. Thus, the final yield was expressed in $\mathrm{kg} \mathrm{ha}^{-1}$ of air-dried fruits. Subsequently, the relative yield was calculated as the ratio between the yield of each treatment and the control yield (without K application).

The agronomic efficiency (AE) was also calculated as the percentage ratio between coffee yields as a result of K sources applied at the same rate; the coffee yield obtained in the treatment without $\mathrm{K}$ application was subtracted from both yields (Goedert \& Lobato, 1984), as follows: $\mathrm{AE}(\%)=[(\mathrm{Y} 2-\mathrm{Y} 1) /(\mathrm{Y} 3-\mathrm{Y} 1)] \times 100$, where: $\mathrm{Y} 1=$ coffee yield in control treatment; $\mathrm{Y} 2=$ coffee yield with alternative source (F2) at the corresponding rate; $\mathrm{Y3}=$ coffee yield with traditional source $(\mathrm{KCl})$ at the corresponding rate. The average of eight control plots determined Y1.

Finally, the amount of macronutrients removed by air-dried fruits was calculated, multiplying the yield per plot by the respective macronutrient concentration in air-dried fruits (values converted to $\left.\mathrm{kg} \mathrm{ha}^{-1}\right)$.

The data were subjected to analyses of variance. Means of sources, in the factorial scheme, were compared by the LSD test at $5 \%$. Effects of K rates were evaluated by regression analysis and, for this purpose, the control (without $\mathrm{K}$ application) was considered as zero rate.

\section{RESULTS AND DISCUSSION}

The concentrations of $\mathrm{N}, \mathrm{P}, \mathrm{Mg}$, and $\mathrm{S}$ in coffee leaves were not affected by $\mathrm{K}$ sources, $\mathrm{K}$ rates or their interactions in either growing season (Table 1). It is noteworthy that the leaf nutrient concentrations in all treatments were within or over the appropriate range for coffee (i.e., $2632 \mathrm{~g} \mathrm{~kg}^{-1}, 1.2$ to $2.0 \mathrm{~g} \mathrm{~kg}^{-1}, 3.0$ to $5.0 \mathrm{~g} \mathrm{~kg}^{-1}$ and 1.5 to $2.0 \mathrm{~g} \mathrm{~kg}^{-1}$ for $\mathrm{N}, \mathrm{P}, \mathrm{Mg}$, and $\mathrm{S}$, respectively) (Raij et al., 1997).

The $\mathrm{K}$ concentration in the coffee leaves was affected only by $\mathrm{K}$ rates (Table 1 ). Regardless of the source, $\mathrm{K}$ application increased leaf $\mathrm{K}$ concentration in the growing season 2008/09. According to Malavolta (1986), the appropriate range of soil available $\mathrm{K}$ is 3.0 to $4.0 \mathrm{mmol}_{\mathrm{c}} \mathrm{dm}^{-3}$ for Arabica coffee. The soil available $\mathrm{K}$ prior to the experiment was $1.0 \mathrm{mmol}_{\mathrm{c}} \mathrm{dm}^{-3}$, i.e., below the appropriate range, with a possible response to K fertilization. In the second growing season (2009/ 10), with lower coffee yield, treatments did not influence K concentration in the coffee leaves (Table 1). However, for all treatments with $\mathrm{K}$ application, leaf $\mathrm{K}$ concentration was within the range from 18 to $25 \mathrm{~g} \mathrm{~kg}^{-1}$, considered appropriate according to Raij et al. (1997), but below the 22 to $25 \mathrm{~g} \mathrm{~kg}^{-1}$ proposed by Malavolta et al. (1997). Nevertheless, Silva et al. (2001) studied $\mathrm{K}$ sources and application rates to coffee cultivar Catuaí Vermelho MG-99 in a growing season with high coffee yield and found that greatest yields were reached at leaf $\mathrm{K}$ concentration of 16.7 and $14.2 \mathrm{~g} \mathrm{~kg}^{-1}$ on a Red Latosol and Red-Yellow Latosol, respectively. Therefore, the appropriate rates depend on several factors, including sampling time. It is important to point out that in both growing seasons the absence of $\mathrm{K}$ application (control) resulted in leaf $\mathrm{K}$ concentration below the appropriate range, indicating that coffee is K-demanding and, although there was no significant effect in the second growing season, the application reasonably increased K leaf concentration, regardless of the $\mathrm{K}$ source or rate.

It was considered that coffee yield was higher in the first than in the second growing season; in other words, the 2008/09 growing season was the highyielding and 2009/10 the low-yielding growing season (Table 1). Therefore, the coffee $\mathrm{K}$ demand was higher in the first growing season, especially in the fruit and grain filling stage with a linear $\mathrm{K}$ rate response model. Arabica coffee has biennial or alternate bearing (higher production every two years), which is typical of the species' physiology, besides being related to the sourcesink ratio between fruits and leaves. This implies that coffee trees have to grow enough leaves in one year to sustain a great production in the following year. Potassium stimulates coffee bean filling and maturation, increasing weight and volume (Malavolta et al., 1974). According to Matiello et al. (2010), N and $\mathrm{K}$ are the most required nutrients by coffee trees, but $\mathrm{N}$ is the most required in the low-yielding growing season (leaf growth) and $\mathrm{K}$ is the most required in the 
Table 1. Effect of sources and rates of potassium fertilization on concentration of N, P, K, Ca, Mg, S, and Si in the leaves and air-dried fruit yield of Arabica coffee

\begin{tabular}{|c|c|c|c|c|c|c|c|c|c|c|}
\hline \multirow{2}{*}{ Growing season } & \multicolumn{2}{|c|}{ Source (S) } & \multicolumn{4}{|c|}{$\mathrm{K}_{2} \mathrm{O}$ rate $\left(\mathrm{kg} \mathrm{ha}^{-1}\right)(\mathrm{R})$} & \multirow{2}{*}{\multicolumn{2}{|c|}{$\mathrm{S} \times \mathrm{R}^{(1)} \mathrm{CV}(\%)$}} & \multirow{2}{*}{ Equation } & \multirow{2}{*}{$\mathbf{R}^{2}$} \\
\hline & F2 & $\mathrm{KCl}$ & $\mathbf{0}$ & 75 & 150 & 300 & & & & \\
\hline \multicolumn{11}{|c|}{$\mathrm{N}$ concentration $\left(\mathrm{g} \mathrm{kg}^{-1}\right)$} \\
\hline $2008 / 09$ & $34.8 \mathrm{a}^{(2)}$ & $35.0 \mathrm{a}$ & 32.1 & 32.9 & 37.9 & 33.9 & ns & 13.9 & $\mathrm{~ns}$ & - \\
\hline $2009 / 10$ & $34.8 \mathrm{a}$ & $36.1 \mathrm{a}$ & 34.1 & 35.4 & 34.6 & 36.4 & ns & 8.7 & $\mathrm{~ns}$ & - \\
\hline \multicolumn{11}{|c|}{$\mathrm{P}$ concentration $\left(\mathrm{g} \mathrm{kg}^{-1}\right)$} \\
\hline $2008 / 09$ & $3.6 \mathrm{a}$ & $3.9 \mathrm{a}$ & 3.9 & 3.5 & 3.9 & 3.9 & ns & 15.1 & $\mathrm{~ns}$ & - \\
\hline $2009 / 10$ & $1.6 \mathrm{a}$ & $1.8 \mathrm{a}$ & 1.7 & 1.7 & 1.7 & 1.6 & ns & 24.4 & $\mathrm{~ns}$ & - \\
\hline \multicolumn{11}{|c|}{$\mathrm{K}$ concentration $\left(\mathrm{g} \mathrm{kg}^{-1}\right)$} \\
\hline $2008 / 09$ & $19.9 \mathrm{a}$ & $21.5 \mathrm{a}$ & 14.8 & 19.6 & 21.2 & 21.3 & ns & 10.4 & $\hat{y}=14.991+0.067^{* *} x-0.0001^{* *} x^{2}$ & 0.98 \\
\hline $2009 / 10$ & $19.7 \mathrm{a}$ & $20.0 \mathrm{a}$ & 17.4 & 19.0 & 20.4 & 20.0 & $\mathrm{~ns}$ & 15.0 & $\mathrm{~ns}$ & - \\
\hline \multicolumn{11}{|c|}{ Ca concentration $\left(\mathrm{g} \mathrm{kg}^{-1}\right)$} \\
\hline $2008 / 09$ & $19.9 \mathrm{a}$ & $21.5 \mathrm{a}$ & 14.8 & 19.6 & 21.2 & 21.3 & ns & 10.4 & $\hat{y}=14.991+0.067^{* *} \mathrm{x}-0.0001^{* *} \mathrm{x}^{2}$ & 0.98 \\
\hline $2009 / 10$ & $19.7 \mathrm{a}$ & $20.0 \mathrm{a}$ & 17.4 & 19.0 & 20.4 & 20.0 & ns & 15.0 & $\mathrm{~ns}$ & - \\
\hline \multicolumn{11}{|c|}{$\mathrm{Mg}$ concentration $\left(\mathrm{g} \mathrm{kg}^{-1}\right)$} \\
\hline $2008 / 09$ & $4.7 \mathrm{a}$ & $5.2 \mathrm{a}$ & 5.1 & 5.0 & 5.1 & 4.6 & ns & 17.0 & $\mathrm{~ns}$ & - \\
\hline $2009 / 10$ & $3.1 \mathrm{a}$ & $3.5 \mathrm{a}$ & 2.9 & 3.1 & 3.6 & 3.3 & ns & 33.8 & $\mathrm{~ns}$ & - \\
\hline \multicolumn{11}{|c|}{$\mathrm{S}$ concentration $\left(\mathrm{g} \mathrm{kg}^{-1}\right)$} \\
\hline $2008 / 09$ & $1.5 \mathrm{a}$ & $2.3 \mathrm{a}$ & 1.7 & 1.8 & 1.6 & 1.5 & ns & 19.3 & $\mathrm{~ns}$ & - \\
\hline $2009 / 10$ & $1.7 \mathrm{a}$ & $1.8 \mathrm{a}$ & 1.6 & 1.8 & 1.7 & 1.6 & ns & 23.0 & $\mathrm{~ns}$ & - \\
\hline \multicolumn{11}{|c|}{ Si concentration $\left(\mathrm{g} \mathrm{kg}^{-1}\right)$} \\
\hline $2008 / 09$ & $1.53 \mathrm{a}$ & $1.27 \mathrm{~b}$ & 1.19 & 1.36 & 1.40 & 1.45 & $*$ & 6.2 & $\hat{y}=1.200+0.002^{* *} x-4 e-6^{* *} x^{2}$ & 0.97 \\
\hline $2009 / 10$ & $1.43 \mathrm{a}$ & $0.47 \mathrm{~b}$ & 0.90 & 1.02 & 0.90 & 0.91 & ns & 13.7 & $\mathrm{~ns}$ & - \\
\hline \multicolumn{11}{|c|}{ Air-dried fruit yield $\left(\mathrm{kg} \mathrm{ha}^{-1}\right)$} \\
\hline $2008 / 09$ & $2930 \mathrm{a}$ & $2820 \mathrm{a}$ & 2253 & 2523 & 3147 & 2955 & ns & 18.8 & $\hat{y}=2185.695+8.356^{* *} \mathrm{x}-0.019^{*} \mathrm{x}^{2}$ & 0.88 \\
\hline $2009 / 10$ & $1982 \mathrm{a}$ & $2200 \mathrm{a}$ & 1320 & 1843 & 2430 & 2001 & ns & 23.8 & $\hat{y}=1271.05+11.657^{* *} x-0.03^{* *} x^{2}$ & 0.95 \\
\hline
\end{tabular}

(1) Interaction considering only factorial two sources $\times$ three rates. ${ }^{(2)}$ Values followed by the same letter in the row, for sources, are not significantly different at $5 \%$ by the LSD test, in the analysis considering only factorial. ns: not significant; * and ** are significant at 5 and $1 \%$, respectively, by the t test.

high-yielding growing season (fruit and grain filling). The results are consistent with those of Silva et al. (2001), who demonstrated that this behavior is due to greater nutrient uptake and thus, a higher nutrient export in the high-yielding growing season.

The $\mathrm{Si}$ concentration in the coffee leaves was affected by the treatments and their interaction in the first growing season, but only by K sources in the second growing season (Table 1). In both growing seasons, F2 application increased leaf Si. According to the $\mathrm{K}$ source $\times \mathrm{K}$ rate interaction, only the $\mathrm{F} 2$ rates increased leaf Si concentrations in the first growing season (Table 2). Best results were obtained with an estimated rate of $250 \mathrm{~kg} \mathrm{~K}_{2} \mathrm{O} \mathrm{ha}^{-1}$ in $\mathrm{F} 2$ form, representing an application of $1560 \mathrm{~kg} \mathrm{ha}^{-1}$ of $\mathrm{SiO}_{2}$, since $\mathrm{F} 2$ contains $52.2 \% \mathrm{SiO}_{2}$. Although Arabica coffee is considered a $\mathrm{Si}$ non-accumulator, this study demonstrated that $\mathrm{Si}$ was translocated from root to shoot and Si may therefore be beneficial to coffee. Marschner (1995) reported that Si activates the monialiasis phenylalanine enzyme and stimulates peroxidases, which are required for lignin biosynthesis, increasing plant resistance against pathogens as well as abiotic stresses (Guntzer et al., 2012).

Potassium rates affected air-dried fruit yield, but no significant effect of $\mathrm{K}$ sources or $\mathrm{K}$ source $\times \mathrm{K}$ rate interactions were observed (Table 1). In both growing seasons, the response models to K rates were quadratic, increasing up to the maximum estimated rate of $220 \mathrm{~kg} \mathrm{ha}^{-1}$ of $\mathrm{K}_{2} \mathrm{O}$ in the 2008/09 growing season and to $195 \mathrm{~kg} \mathrm{ha}^{-1}$ in 2009/10. Oliveira \& Pereira (1987) also reached highest yields with the application of 200 $\mathrm{kg} \mathrm{ha}{ }^{-1}$ of $\mathrm{K}_{2} \mathrm{O}$ in form of $\mathrm{KCl}$ for cultivar 'Catuaí Amarelo', with soil $\mathrm{K}$ of $1.0 \mathrm{mmol}_{\mathrm{c}} \mathrm{dm}^{-3}$; these conditions were very similar to those of this study. Silva et al. (2001) studied the effects of K sources (KCl, potassium sulfate $\left(\mathrm{K}_{2} \mathrm{SO}_{4}\right)$ and potassium nitrate $\left.\left(\mathrm{KNO}_{3}\right)\right)$ as well as $\mathrm{K}$ rates applied to cultivar Catuaí Vermelho MG-99, and reported that the maximum coffee green bean yield could not be reached by applying the highest $\mathrm{K}_{2} \mathrm{O}$ rate $\left(482 \mathrm{~kg} \mathrm{ha}^{-1}\right)$ in the 
low-yielding growing season. However, in the highyielding growing season, maximum yields were reached with an application of 247.7 and $252.3 \mathrm{~kg} \mathrm{ha}^{-1}$ $\mathrm{K}_{2} \mathrm{O}$, to a Red Latosol (soil available $\mathrm{K} 1.8 \mathrm{mmol}_{\mathrm{c}} \mathrm{dm}^{-3}$ ) and a Red-yellow Latosol (soil available K 1.6 $\mathrm{mmol}_{\mathrm{c}} \mathrm{dm}^{-3}$ ), respectively. According to those authors, maximum yields were reached with mean soil $\mathrm{K}$ of $3.4 \mathrm{mmol}_{\mathrm{c}} \mathrm{dm}^{-3}$ and mean leaf $\mathrm{K}$ concentration of $15.5 \mathrm{~g} \mathrm{~kg}^{-1}$, in the high-yielding growing season.

The yield reduction at the highest $\mathrm{K}$ rate (Table 1 ) indicates a possible nutritional imbalance as a result of cationic competition among $\mathrm{K}, \mathrm{Ca}$, and $\mathrm{Mg}$ and anionic competition among $\mathrm{Cl}, \mathrm{S}$, and $\mathrm{P}$ (Jakobsen, 1993; Clemente et al., 2013). According to Alvarez V. et al. (1999), the probability of coffee response to $\mathrm{K}$ fertilization is high, if soil K concentration ranges from 1.0 to $1.75 \mathrm{mmol}_{\mathrm{c}} \mathrm{dm}^{-3}$. Nevertheless, Silva et al. (2001) observed K fertilization effects on coffee when soil K concentration in a Red Latosol was $1.8 \mathrm{mmol}_{\mathrm{c}} \mathrm{dm}^{-3}$ and the highest yields were harvested at a mean available soil $\mathrm{K}$ of 6.4 and $4.0 \mathrm{mmol}_{\mathrm{c}} \mathrm{dm}^{-3} \mathrm{~K}$ (Mehlich-1) in low and high-yielding growing seasons, respectively.

Even though there was no significant effect on airdried fruit yield by the $\mathrm{K}$ sources or the source $\times$ rate interaction (Table 1), the yield increase as affected by $\mathrm{K}$ rates (Table 3 ), showed that the greatest yield increase was influenced by application of $150 \mathrm{~kg} \mathrm{ha}^{-1}$ $\mathrm{K}_{2} \mathrm{O}$, especially in $\mathrm{F} 2$ form in the first growing season $\left(1,979 \mathrm{~kg} \mathrm{ha}^{-1}\right)$, with a $150 \%$ increase compared to the control, i.e., F2 application induced a 1.5-times higher yield compared to the plots without $\mathrm{K}$ application. This result is better than that of $\mathrm{KCl}$ application, with a $127 \%$ increase compared to the control. In the 2009/10 growing season, $\mathrm{KCl}$ obtained better results than $\mathrm{F} 2$ at the rates of 75 and 300 $\mathrm{kg} \mathrm{ha}^{-1} \mathrm{~K}_{2} \mathrm{O}$. However, at $150 \mathrm{~kg} \mathrm{ha}^{-1} \mathrm{~K}_{2} \mathrm{O}$, F2 application increased the yield by $87 \%$ compared to the control, while $\mathrm{KCl}$ application increased yields by only $81 \%$.

In the first growing season, the agronomic efficiency (AE) of F2 was better, except at $300 \mathrm{~kg} \mathrm{ha}^{-1}$ $\mathrm{K}_{2} \mathrm{O}$ (Table 3). In the second growing season, F2 was more efficient than $\mathrm{KCl}$ to supply $\mathrm{K}$ to coffee only at the rate of $150 \mathrm{~kg} \mathrm{ha}^{-1} \mathrm{~K}_{2} \mathrm{O}$. In the mean of both growing seasons, the AE of $\mathrm{F} 2$ was $13 \%$ higher than that of $\mathrm{KCl}$ rates. Thus, it seems that $\mathrm{F} 2$ can be used as $\mathrm{K}$ source for coffee, with similar results to those with KCl. Guelfi-Silva et al. (2013) studied coffee plant nutrition and fertilization efficiency under alternative $\mathrm{K}$ sources and concluded that rock powder can be used as nutrient source. However, AE decreases at rates of over $200 \mathrm{~kg} \mathrm{ha}^{-1} \mathrm{~K}_{2} \mathrm{O}$. The agronomic efficiency depends on the rock $\mathrm{K}$ solubility and thus, materials in which $\mathrm{K}$ is bound to minerals that are more quickly solubilized, e.g., silicate rocks, usually release K to the soil solution faster as well (Guelfi-Silva et al., 2013).

In addition, it must be highlighted that in the present study, only one annual $\mathrm{K}$ source application was performed (October/November) to compare the sources under the same conditions. Therefore, considering that the recommended split application of soluble $\mathrm{K}$ sources with the main objective of decreasing nutrient losses by leaching (Raij et al., 1997), and that high-rate applications can cause plant nutrition imbalance (Jakobsen, 1993), the lowest yield as a result of $300 \mathrm{~kg} \mathrm{ha}^{-1} \mathrm{~K}_{2} \mathrm{O}$ application in our study may be due to soil $\mathrm{K}$ excess. The soil already contained an average concentration of this

Table 3. Effect of sources and rates of $K$ fertilization on increases in yield and relative yield of airdried fruit of coffee Arabica crop and agronomic efficiency (AE) of three $\mathrm{F} 2$ rates compared to $\mathrm{KCl}$

\begin{tabular}{|c|c|c|c|c|}
\hline \multirow{2}{*}{$\mathrm{K}_{2} \mathrm{O}$ rate } & \multicolumn{2}{|c|}{ Increased yield $^{(1)}$} & \multicolumn{2}{|c|}{${\text { Relative } \text { yield }^{(2)}}^{(2)}$} \\
\hline & F2 & $\mathrm{KCl}$ & F2 & $\mathrm{KCl}$ \\
\hline
\end{tabular}

\begin{tabular}{cccccr}
\hline $\mathrm{kg} \mathrm{ha}^{-1}$ & \multicolumn{3}{c}{$\mathrm{kg} \mathrm{ha}^{-1}$} & & \multicolumn{3}{c}{$\%$} \\
\cline { 5 - 6 } \cline { 5 - 6 } 75 & 1255.1 & 1152.0 & 195.1 & 187.3 & 108.9 \\
150 & 1979.4 & 1673.9 & 250.0 & 226.8 & 118.3 \\
300 & 1597.2 & 1673.0 & 221.0 & 226.7 & 95.5 \\
Mean & - & - & - & - & 107.6 \\
& & & $2009 / 10$ & & \\
75 & 266.7 & 779.3 & 120.2 & 159.0 & 34.2 \\
150 & 1148.1 & 1071.3 & 187.0 & 181.2 & 107.2 \\
300 & 572.6 & 789.3 & 143.4 & 159.8 & 72.5 \\
Mean & - & - & - & - & 71.3 \\
\hline
\end{tabular}

(1) Increased yield in relation to average yield of the control. ${ }^{(2)}$ Relative yield in relation to the control mean (control $=100 \%$ ).

Table 2. Effect of $\mathrm{K}$ fertilizer source $\times$ rate interaction on $\mathrm{Si}$ leaf concentration of Arabica coffee, in the 2008/ 09 growing season

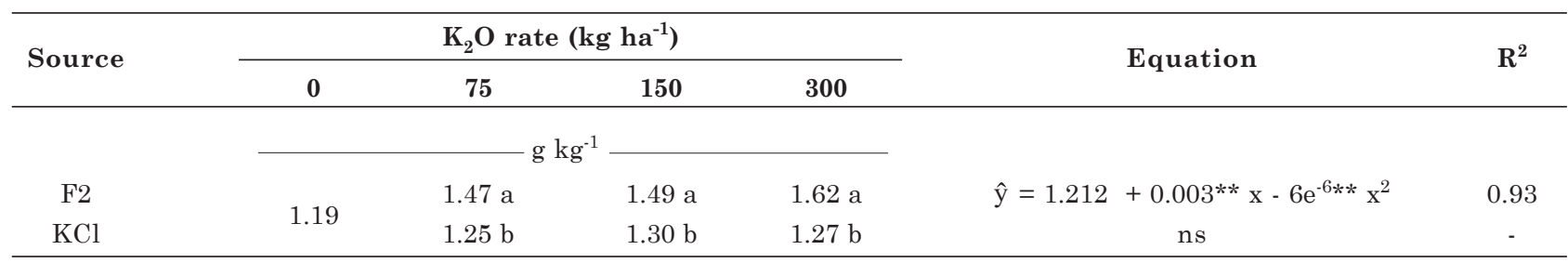

Values followed by the same letter in the column, within the rates of 75,150 , and $300 \mathrm{~kg} \mathrm{ha}^{-1} \mathrm{~K}_{2} \mathrm{O}$, are not significantly different at $5 \%$ according to the LSD test. ns: not significant; ** significant at $1 \%$ by the test. 
element $\left(1.1 \mathrm{mmol}_{\mathrm{c}} \mathrm{dm}^{-3}\right)$, even when $\mathrm{F} 2$ was applied, which may have inhibited the uptake of other nutrients (Jakobsen, 1993; Malavolta et al., 1997). Moreover, despite the presence of some potentially harmful elements to the plants at relatively high F2 levels, such as Al, according to Cortes et al. (2010), because the $\mathrm{pH}$ of $\mathrm{F} 2$ is basic ( 10.4) there is no $\mathrm{Al}$ reaction in the soil, especially in the one with less acidic $\mathrm{pH}$.
According to Kaminski \& Rheinheimer (2000), hexahydrate $\mathrm{Al}\left[\mathrm{Al}\left(\mathrm{H}_{2} \mathrm{O}\right)_{6}{ }^{3+}\right]$ deprotonates and disappears at $\mathrm{pH}>5.5$, causing no more damage to the plants.

Another aspect is that in both growing seasons the effects of both sources were similar, i.e., there was no statistical difference between $\mathrm{KCl}$ or $\mathrm{F} 2$ application (Table 1). This demonstrates that F2 is

Table 4. Effect of sources and rates of potassium fertilization on concentration and export of N, P, K, Ca, Mg, and $\mathrm{S}$ in air-dried fruit of Arabica coffee

\begin{tabular}{|c|c|c|c|c|c|c|c|c|c|c|}
\hline \multirow{2}{*}{ Growing season } & \multicolumn{2}{|c|}{ Source (S) } & \multicolumn{4}{|c|}{$\mathrm{K}_{2} \mathrm{O}$ rate $\left(\mathrm{kg} \mathrm{ha}^{-1}\right)(\mathrm{R})$} & \multirow{2}{*}{\multicolumn{2}{|c|}{$S \times R^{(1)} \mathbf{C V}(\%)$}} & \multirow{2}{*}{ Equation } & \multirow{2}{*}{$\mathbf{R}^{2}$} \\
\hline & F2 & $\mathrm{KCl}$ & $\mathbf{0}$ & 75 & 150 & 300 & & & & \\
\hline \multicolumn{11}{|c|}{$\mathrm{N}$ concentration $\left(\mathrm{g} \mathrm{kg}^{-1}\right)$} \\
\hline $2008 / 09$ & $21.9 \mathrm{a}^{(2)}$ & $22.0 \mathrm{a}$ & 20.4 & 21.6 & 22.3 & 21.9 & $\mathrm{~ns}$ & 5.6 & $\hat{y}=20.433+0.02^{* *} \mathrm{x}-0.00005^{*} \mathrm{x}^{2}$ & 0.99 \\
\hline $2009 / 10$ & $21.6 \mathrm{a}$ & $22.0 \mathrm{a}$ & 26.3 & 21.2 & 21.9 & 22.3 & $\mathrm{~ns}$ & 18.8 & $\mathrm{~ns}$ & - \\
\hline \multicolumn{11}{|c|}{$\mathrm{P}$ concentration $\left(\mathrm{g} \mathrm{kg}^{-1}\right)$} \\
\hline $2008 / 09$ & $0.9 \mathrm{a}$ & $0.9 \mathrm{a}$ & 0.9 & 0.9 & 0.9 & 0.9 & $\mathrm{~ns}$ & 15.0 & $\mathrm{~ns}$ & - \\
\hline $2009 / 10$ & $0.8 \mathrm{a}$ & $0.7 \mathrm{a}$ & 0.8 & 0.9 & 0.6 & 0.6 & $\mathrm{~ns}$ & 24.9 & ns & - \\
\hline \multicolumn{11}{|c|}{$\mathrm{K}$ concentration $\left(\mathrm{g} \mathrm{kg}^{-1}\right)$} \\
\hline $2008 / 09$ & $23.8 \mathrm{a}$ & $22.9 \mathrm{a}$ & 19.1 & 22.5 & 22.6 & 25.0 & $\mathrm{~ns}$ & 11.8 & $\hat{y}=19.04+0.0273^{* *} \mathrm{x}$ & 0.87 \\
\hline $2009 / 10$ & $29.6 \mathrm{a}$ & $30.7 \mathrm{a}$ & 27.0 & 32.5 & 28.2 & 29.6 & $\mathrm{~ns}$ & 22.7 & $\mathrm{~ns}$ & - \\
\hline \multicolumn{11}{|c|}{ Ca concentration $\left(\mathrm{g} \mathrm{kg}^{-1}\right)$} \\
\hline $2008 / 09$ & $2.2 \mathrm{a}$ & $2.1 \mathrm{a}$ & 2.2 & 2.3 & 2.1 & 3.0 & $\mathrm{~ns}$ & 28.2 & $\hat{y}=2.050+0.003^{*} x$ & 0.68 \\
\hline $2009 / 10$ & $2.7 \mathrm{a}$ & $2.9 \mathrm{a}$ & 2.6 & 2.6 & 2.4 & 3.4 & $\mathrm{~ns}$ & 26.0 & $\hat{y}=2.415+0.003^{*} \mathrm{x}$ & 0.57 \\
\hline \multicolumn{11}{|c|}{$\mathrm{Mg}$ concentration $\left(\mathrm{g} \mathrm{kg}^{-1}\right)$} \\
\hline $2008 / 09$ & $2.2 \mathrm{a}$ & $2.1 \mathrm{a}$ & 2.2 & 2.1 & 2.2 & 2.1 & $\mathrm{~ns}$ & 9.8 & $\mathrm{~ns}$ & - \\
\hline $2009 / 10$ & $1.7 \mathrm{a}$ & $1.7 \mathrm{a}$ & 1.5 & 1.7 & 1.5 & 1.8 & $\mathrm{~ns}$ & 24.3 & $\mathrm{~ns}$ & - \\
\hline \multicolumn{11}{|c|}{$\mathrm{S}$ concentration $\left(\mathrm{g} \mathrm{kg}^{-1}\right)$} \\
\hline $2008 / 09$ & $1.5 \mathrm{a}$ & $1.5 \mathrm{a}$ & 1.4 & 1.5 & 1.5 & 1.5 & $\mathrm{~ns}$ & 6.2 & $\mathrm{~ns}$ & - \\
\hline $2009 / 10$ & $0.6 \mathrm{a}$ & $0.7 \mathrm{a}$ & 0.6 & 0.8 & 0.6 & 0.6 & $\mathrm{~ns}$ & 18.9 & ns & - \\
\hline \multicolumn{11}{|c|}{$\mathrm{N}$ export $\left(\mathrm{kg} \mathrm{ha}^{-1}\right)$} \\
\hline $2008 / 09$ & $56.7 \mathrm{a}$ & $54.6 \mathrm{a}$ & 40.4 & 48.0 & 61.8 & 56.9 & $\mathrm{~ns}$ & 19.7 & $\hat{y}=39.01+0.205^{* *} \mathrm{x}-0.0006^{* *} \mathrm{x}^{2}$ & 0.91 \\
\hline $2009 / 10$ & $37.2 \mathrm{a}$ & $38.4 \mathrm{a}$ & 34.6 & 32.3 & 48.9 & 35.5 & $\mathrm{~ns}$ & 36.1 & $\mathrm{~ns}$ & - \\
\hline \multicolumn{11}{|c|}{$\mathrm{P}$ export $\left(\mathrm{kg} \mathrm{ha}^{-1}\right)$} \\
\hline $2008 / 09$ & $2.3 \mathrm{a}$ & $2.2 \mathrm{a}$ & 1.8 & 2.0 & 2.5 & 2.3 & $\mathrm{~ns}$ & 20.1 & $\hat{y}=1.92+0.002^{*} x$ & 0.52 \\
\hline $2009 / 10$ & $1.4 \mathrm{a}$ & $1.4 \mathrm{a}$ & 0.9 & 1.5 & 1.3 & 1.1 & $\mathrm{~ns}$ & 32.0 & $\mathrm{~ns}$ & - \\
\hline \multicolumn{11}{|c|}{$\mathrm{K}$ export $\left(\mathrm{kg} \mathrm{ha}^{-1}\right)$} \\
\hline $2008 / 09$ & $61.4 \mathrm{a}$ & $56.8 \mathrm{a}$ & 37.9 & 50.0 & 62.6 & 65.0 & $\mathrm{~ns}$ & 23.2 & $\hat{y}=37.232+0.227^{* *} \mathrm{x}-0.0004^{*} \mathrm{x}^{2}$ & 0.99 \\
\hline $2009 / 10$ & $51.6 \mathrm{a}$ & $59.4 \mathrm{a}$ & 31.4 & 52.7 & 60.3 & 52.1 & $\mathrm{~ns}$ & 30.5 & $\hat{y}=31.88+0.325^{* *} x-0.0009^{*} x^{2}$ & 0.99 \\
\hline \multicolumn{11}{|c|}{$\mathrm{Ca}$ export $\left(\mathrm{kg} \mathrm{ha}^{-1}\right)$} \\
\hline $2008 / 09$ & $5.7 \mathrm{a}$ & $5.2 \mathrm{a}$ & 4.4 & 5.1 & 5.8 & 7.8 & $\mathrm{~ns}$ & 31.6 & $\hat{y}=4.28+0.0114^{* *} \mathrm{x}$ & 0.99 \\
\hline $2009 / 10$ & $4.7 \mathrm{a}$ & $5.6 \mathrm{a}$ & 3.0 & 4.2 & 5.1 & 6.0 & $\mathrm{~ns}$ & 33.5 & $\mathrm{~ns}$ & - \\
\hline \multicolumn{11}{|c|}{$\mathrm{Mg}$ export $\left(\mathrm{kg} \mathrm{ha}^{-1}\right)$} \\
\hline $2008 / 09$ & $5.7 \mathrm{a}$ & $5.2 \mathrm{a}$ & 4.4 & 4.7 & 6.1 & 5.5 & $\mathrm{~ns}$ & 20.4 & $\hat{y}=4.217+0.016^{* *} \mathrm{x}-0.00004^{*} \mathrm{x}^{2}$ & 0.77 \\
\hline $2009 / 10$ & $3.0 \mathrm{a}$ & $3.3 \mathrm{a}$ & 1.7 & 2.8 & 3.2 & 3.2 & $\mathrm{~ns}$ & 28.2 & $\hat{y}=1.736+0.016^{* *} x-0.00004^{*} x^{2}$ & 0.99 \\
\hline \multicolumn{11}{|c|}{$\mathrm{S}$ export $\left(\mathrm{kg} \mathrm{ha}^{-1}\right)$} \\
\hline $2008 / 09$ & $3.9 \mathrm{a}$ & $3.7 \mathrm{a}$ & 2.8 & 3.3 & 4.2 & 3.9 & $\mathrm{~ns}$ & 18.5 & $\hat{y}=2.71+0.013^{* *} x-0.00003^{*} x^{2}$ & 0.87 \\
\hline $2009 / 10$ & $1.0 \mathrm{a}$ & $1.4 \mathrm{a}$ & 0.7 & 1.3 & 1.3 & 1.1 & $\mathrm{~ns}$ & 25.8 & $\hat{y}=0.744+0.007^{*} x-0.00002^{*} x^{2}$ & 0.90 \\
\hline
\end{tabular}

(1) Interaction considering only factorial two sources $\times$ three rates. ${ }^{(2)}$ Values followed by the same letter in the row, for sources, are not significantly different at $5 \%$ by the LSD test, in the analysis considering only factorial. ns: not significant; * and ** are significant at 5 and $1 \%$, respectively, by the t test. 
as efficient in supplying $\mathrm{K}$ to coffee as $\mathrm{KCl}$, increasing yield in the same way (Tables 1 and 2). However, F2 transportation cost may be more expensive, because of the lower $\mathrm{K}_{2} \mathrm{O}$ concentration of $\mathrm{F} 2$ than $\mathrm{KCl}$, and thus, more F2 is required to supply coffee at the recommended rate. Hence, the viability of $\mathrm{F} 2$ application in agriculture as much as that of any other fertilizer or acidity corrective depends mostly on the distance between the point of extraction and the farm where it will be applied (Guelfi-Silva et al., 2013).

In relation to nutrient concentration in air-dried coffee fruits, there was no significant effect of sources and the source $\mathrm{x}$ rate interaction for any of the nutrients evaluated (Table 4). Potassium rates did not affect $\mathrm{P}, \mathrm{Mg}$, and $\mathrm{S}$ concentrations in air-dried fruits either, in either growing season. On the other hand, $\mathrm{K}$ rates affected $\mathrm{N}$ and $\mathrm{K}$ concentrations in airdried coffee fruits in the 2008/09 growing season, besides $\mathrm{Ca}$ concentration in both growing seasons. Potassium fertilizer application increased N, K, and $\mathrm{Ca}$ concentrations in air-dried coffee fruits. Potassium and $\mathrm{N}$ were found in greater concentrations in airdried coffee fruits. Catani et al. (1967) evaluated the dry matter of 1,000 coffee fruits, harvested at the fresh ripe cherry stage, and found ideal macronutrient concentrations $\left(15.3 ; 1.6 ; 23.3 ; 3.1 ; 0.7\right.$, and $0.9 \mathrm{~g} \mathrm{~kg}^{-1}$ of N, P, K, Ca, Mg, and S, respectively). Similar results were found in this study.

Potassium sources did not affect significantly macronutrient removal in air-dried fruits in both growing seasons (Table 4). On the other hand, K rates influenced all macronutrients exported in the 2008/ 09 growing season, as well as $\mathrm{K}, \mathrm{Mg}$, and $\mathrm{S}$ removal in air-dried fruits in the following growing season. The quadratic regression model fitted best for all exported macronutrients, except $\mathrm{P}$ in the first growing season, to which a linear regression model fitted better (Table 4). A comparison of both growing seasons showed that removal was higher in the first growing season probably because of higher in airdried fruit yield (Table 1), i.e., the coffee yield was higher in the 2008/09 than the 2009/10 growing season, inducing a greater nutritional demand, especially of $\mathrm{K}$ and $\mathrm{N}$ in the first growing season. This was due to the higher nutrient uptake by coffee trees and hence increased nutrient removal by airdried fruits in the higher-yielding growing season (Silva et al., 2001). Therefore, nutrient export by coffee demonstrates the need for well-adjusted fertilization to reach higher yields.

In general, the nutrients removed in air-dried coffee fruits, in decreasing order, were: $\mathrm{K}>\mathrm{N}>\mathrm{Ca}>\mathrm{Mg}>\mathrm{S}>\mathrm{P}$, in all treatments and in the mean of both growing seasons. Raij (2007) reported that the mean removal of primary macronutrients in coffee beans in Brazil is $31.0,1.5$, and $47.3 \mathrm{~kg} \mathrm{ha}^{-1}$ of $\mathrm{N}, \mathrm{P}$, and $\mathrm{K}$, respectively, as similarly found in this study, especially for the second growing season.

\section{CONCLUSIONS}

1. Potassium application increased Arabica coffee yield, regardless of the source.

2. The application of phonolite rock powder (F2) increased the air-dried fruit yield similarly to $\mathrm{KCl}$ application at the recommended $\mathrm{K}$ rate for coffee (150 $\mathrm{kg} \mathrm{ha}^{-1} \mathrm{~K}_{2} \mathrm{O}$ ).

3. Potassium application increased macronutrients export by coffee, especially in the high-yielding growing season.

\section{ACKNOWLEDGEMENTS}

The authors are indebted to Unimesp Agribusiness Company, for granting access to the experimental field, to Mineração Curimbaba, for providing the phonolite rock powder (F2) as K source, and to the National Council for Scientific and Technological Development (CNPq) for research awards to the second and third authors.

\section{LITERATURE CITED}

ALVAREZ V., V.H.; NOVAIS, R.F.; BARROS, N.F.; CANTARUTTI, R.B. \& LOPES, A.S. Interpretação dos resultados das análises de solos. In: RIBEIRO, A.C.; GUIMARÃES, P.T.G. \& ALVAREZ V., V.H., eds. Recomendações para o uso de corretivos e fertilizantes em Minas Gerais: $5^{\text {a }}$ aproximação. Viçosa, MG, Comissão de Fertilidade do Solo do Estado de Minas Gerais, 1999. p.25-32.

BRASIL. Ministério de Minas e Energia. Cadeia de fertilizantes Relatório Técnico 75: Perfil dos Fertilizantes N, Pe K. Available at: <http://www.mme.gov.br/sgm/galerias/arquivos/ plano_duo_decenal/a_transformacao_mineral_no_brasil/ P49_RT75_Perfil_dos_Fertilizantes_N-P-K.pdf>. Accessed: 03 April 2012.

CATANI, R.A.; PELlEGRINO, D.; ALCARDE, J.C. \& GRANER, C.A.F. Variação na concentração e na quantidade de macro e micronutrientes no fruto do cafeeiro, durante o seu desenvolvimento. Anais ESALQ, 24:249-263, 1967.

CHALFOUN, S.M. \& CARVALHO, V.L. Doenças e nematóides em cafeeiros. In: GUIMARÃES, R.J.; MENDES, A.N.G. \& SOUZA, C.A.S., eds. Cafeicultura. 4.ed. Lavras, Universidade Federal de Lavras, 2002. p.262-276.

CLEMENTE, J.M.; MARTINEZ, H.E.P.; ALVES, L.C. \& LARA, M.C.R. Effect of $\mathrm{N}$ and $\mathrm{K}$ doses in nutritive solution on growth, production and coffee bean size. R. Ceres, 60:279$285,2013$.

COMPANHIA NACIONAL DE ABASTECIMENTO - CONAB. Acompanhamento da Safra Brasileira Café Safra 2013 primeira estimativa: janeiro/2013. Available at: <http:// www.conab.gov.br/OlalaCMS/uploads/arquivos/ 13_01_09_17_43_49_boletim_cafe_janeiro_2013.pdf $>$. Accessed: 06 May 2013. 
CORTES, G.P.; FERREIRA, R.C.; CORTES, G.P.; RAMPAZZO, L. \& FERREIRA, L.C. Fonolito como substituto do cloreto de potássio e/ou outras fontes de potássio na agricultura e pecuária do Brasil. In: CONGRESSO BRASILEIRO DE ROCHAGEM, 1., Planaltina, 2010. Anais... Planaltina, Embrapa Cerrados, 2010. p.75-86.

DUARTE, I.N.; PEREIRA, H.S. \& KORNDORFER, G.H. Lixiviação de potássio proveniente do termopotássio. Pesq. Agropec. Trop., 43:195-200, 2013.

EMPRESA BRASILEIRA DE PESQUISA AGROPECUÁRIA EMBRAPA. Centro Nacional de Pesquisa de Solos. Manual de métodos de análise de solo. 2.ed. Rio de Janeiro, Embrapa Solos, 1997. 212p.

EMPRESA BRASILEIRA DE PESQUISA AGROPECUÁRIA EMBRAPA. Centro Nacional de Pesquisa de Solos. Sistema brasileiro de classificação de solos. 2.ed. Rio de Janeiro, Embrapa Solos, 2006. 306p.

GOEDERT, W.J. \& LOBATO, E. Avaliação agronômica de fosfatos em solo de cerrado. R. Bras. Ci. Solo, 8:97-102, 1984.

GUELFI-SILVA，D.R.; MARCHI，G.; SPEHAR， C.R.; GUILHERME, L.R.G. \& FAQUIN, V. Eficiência agronômica da adubação potássica na alface adubada com fontes alternativas de nutrientes. R. Ci. Agron., 44:267$277,2013$.

GUNTZER, F.; KELLER, C. \& MEUNIER, J.D. Benefits of plant silicon for crops: A review. Agron. Sust. Develop., 32:201-213, 2012.

JAKOBSEN, S.T. Nutritional disorders between potassium, magnesium, calcium, and phosphorus in soil. Plant Soil, 154:21-28, 1993.

KAMINSKI, J. \& RHEINHEIMER, D.S. A acidez do solo e a nutrição mineral de plantas. In: KAMINSKI, J., coord. Uso de corretivos da acidez do solo no plantio direto. Pelotas, SBCS/Núcleo Regional Sul, 2000. p.21-39.

KORNDÖRFER, G.H.; NOLLA, A. \& OLIVEIRA, L.A. Análise de silício: Solo, planta e fertilizante. Uberlândia, GPSiICIAG-UFU, 2004. 39p. (Boletim Técnico, 2)

MALAVOLTA, E. Nutrição, adubação e calagem para o cafeeiro. In: RENA, A.B.; MALAVOLTA, E.; ROCHA, M. \& YAMADA, T., eds. Cultura do cafeeiro: Fatores que afetam a produtividade. Piracicaba, Potafos, 1986. p.136-274.

MALAVOLTA, E.; HAAG, H.P.; MELLO, F.A.F.; BRASIL SOBRINHO, M.O.C. \& MELLO, F.A.F. Nutrição mineral e adubação do cafeeiro. In: MALAVOLTA, E.; HAAG, H.P.; MELLO, F.A.F.; BRASIL SOBRINHO, M.O.C. \& MELLO, F.A.F., eds. Nutrição mineral e adubação de plantas cultivadas. São Paulo, Pioneira, 1974. p.203-255.

MALAVOLTA, E.; VITTI, G.C. \& OLIVEIRA, S.A. Avaliação do estado nutricional de plantas: princípios e aplicações. 2.ed. Piracicaba, Potafos, 1997. 308p.

MARSCHNER, H. Mineral nutrition of higher plants. 2.ed. New York, Academic Press, 1995. 450p.
MATIELLO, J.B.; SANTINATO, R.; GARCIA, A.W.R.; ALMEIDA, S.R. \& FERNANDES, D.R. Cultura de café no Brasil: Manual de recomendações. 3.ed. Rio de Janeiro, MAPA/Procafe, 2010. 542p.

MELAMED, R.; GASPAR, J.C. \& MIEKELEY, N. Pó-de-rocha como fertilizante alternativo para sistemas de produção sustentáveis em solos tropicais. In: LAPIDOLOUREIRO, F.E.V.; MELAMED, R. \& FIGUEIREDO NETO, J., eds. Fertilizantes: Agroindústria e sustentabilidade. Rio de Janeiro, CETEM/MCT, 2009. p.385-395.

OLIVEIRA, J.A. \& PEREIRA, J.E. Efeito da adubação nitrogenada e potássica na formação e produção do cafeeiro em LVHd. In: CONGRESSO BRASILEIRO DE PESQUISAS CAFEEIRAS, 14., Rio de Janeiro, 1987. Anais... Rio de Janeiro, IBC/GERCA, 1987. p.133-136.

RAIJ, B.van. A fertilização do cafeeiro no Brasil e o desenvolvimento sustentável. In: ZAMBOLIM, L., ed. Boas práticas agrícolas na produção de café. Viçosa, MG, Universidade Federal de Viçosa, 2007. p.61-82.

RAIJ, B.van; ANDRADE, J.C.; CANTARELLA, H. \& QUAGGIO, J.A. Análise química para avaliação da fertilidade de solos tropicais. 3.ed. Campinas, IAC, 2001. $284 \mathrm{p}$.

RAIJ, B.van; FERNANDES, D.R.; OLIVEIRA, E.G. \& MALAVOLTA, E. Café. In: RAIJ, B.van; CANTARELLA, H.; QUAGGIO, J.A. \& FURLANI, A.M.C., eds. Recomendações de adubação e calagem para o Estado de São Paulo. 2.ed. Campinas, Instituto Agronômico de Campinas, 1997. p.97-101. (Boletim Técnico, 100)

RESENDE, A.V.; MARTINS, E.S.; OLIVEIRA, C.G.; SENA, M.C.; MACHADO, C.T.T.; KINPARA, D.I. \& OLIVEIRA FILHO, E.C. Suprimento de potássio e pesquisa de uso de rochas "in natura" na agricultura brasileira. Esp. Geogr., 9:19-42, 2006.

SILVA, E.B.; NOGUEIRA, F.D. \& GUIMARÃES, P.T.G. Qualidade de grãos de café beneficiados em resposta à adubação potássica. Sci. Agric., 59:173-179, 2002.

SILVA, E.B.; NOGUEIRA, F.D.; GUIMARÃES, P.T.G. \& FURTINI NETO, A.E. Respostas do cafeeiro à adubação potássica para baixa e alta produção. Pesq. Agropec. Bras., 36:1331-1337, 2001.

SILVA, E.B.; NOGUEIRA, F.D.; GUIMARÃES, P.T.G.; CHAGAS, S.J.R. \& COSTA, L. Fontes e doses de potássio na produção e qualidade do grão de café beneficiado. Pesq. Agropec. Bras., 34:335-345, 1999.

TEIXEIRA, A.M.S.; SAMPAIO, J.A.; GARRIDO, F.M.S. \& MEDEIROS, M.E. Technological characterization of phonolite rock to be applied as source of nutrients to the Brazilian agriculture. In: MONTEIRO, S.N.; VERHULST, D.E.; ANYALEBECHI, P.N. \& POMYKALA, J.A., eds. EPD Congress 2011. Hoboken-USA, John Wiley \& Sons, 2011. p.81-86. 